\title{
Soil Properties and Crop Yield under Different Tillage Practices in Upland of Balochistan
}

\author{
Muhammad Sharif $^{*}$, Sadullah ${ }^{1}$, Ghulam Rasool ${ }^{2}$, Muhammad Nasir Khan ${ }^{1}$, Zubair Rehman ${ }^{1}$, Ahmed \\ Khan $^{2}$, Ijaz Ahmad ${ }^{3}$ and Khalid Hussain ${ }^{4}$
}

${ }^{1}$ Department of Soil Science, Balochistan Agriculture College, Quetta, Pakistan; ${ }^{2}$ Balochistan Agriculture College, Quetta, Pakistan; ${ }^{3}$ Ecotoxicology Research Institute, National Agriculture Research Centre, Islamabad, Pakistan; ${ }^{4}$ Department of Agronomy, University of Agriculture Faisalabad, Pakistan.

Abstract | Soil degradation due to structural instability and low contents of organic matters are serious challenges for land and crop production in the upland of Balochistan. It is important to explore an alternative farming system which improves soil properties, environment friendly and provide sufficient crop yield. Conservation tillage system is successfully practiced worldwide as a resource conserving techniques. Therefore, an experiment was conducted under the treatments, i.e. conventional tillage (CT), Zero tillage (ZT) and Chisel plough (CP) during the year 2016 at the field research area of Balochistan Agriculture College, Quetta. The study was designed to compare conventional versus conservation tillage practices and their effects on soil physico-chemical properties such as total organic carbon (TOC), infiltration rates, soil water contents (SWC), soil reaction $(\mathrm{pH})$, electrical conductivity (EC), soil bulk density, total soil porosity, soil temperature, crop biomass and crop yield. The results revealed that TOC under ZT (0.57\%) was increased significantly. EC of ZT $\left(0.314 \mathrm{ds} \mathrm{m}^{-1}\right)$ was decreased numerically, but $\mathrm{pH}$ was not affected by tillage treatments. No significant difference regarding SWC, soil temperature, infiltration rate was observed under different tillage treatments, but the results under ZT were appriciable and CT $\left(1.28 \mathrm{~g} \mathrm{~cm}^{-3}\right)$ showed significantly less soil bulk density as compared to both of the other treatments. The crop biomass and grain yield of sorghum were observed $\mathrm{CT}>\mathrm{CP}>\mathrm{ZT}$ accordingly, but the differences were statistically significant for grain yield only. The results indicated that conservation tillage in the form of zero tillage has potential to improve soil properties but the yields of different treatments were same.

Received | January, 30, 2019; Accepted | May 30, 2019; Published | August 12, 2019

*Correspondence | Muhammad Sharif, Department of Soil Science, Balochistan Agriculture College, Quetta, Pakistan; Email:sharifbaloch84@ yahoo.com

Citation | Sharif, M., Sadullah, G. Rasool, M.N. Khan, Z. Rehman, A. Khan, I. Ahmad and K. Hussain. 2019. Soil properties and crop yield under different tillage practices in upland of Balochistan. Pakistan Journal of Agricultural Research, 32(3): 535-543.

DOI | http://dx.doi.org/10.17582/journal.pjar/2019/32.3.535.543

Keywords | Conventional tillage, Conservation tillage, Zero Tillage, Chisel plough

\section{Introduction}

$\mathrm{B}$ alochistan is the largest province of Pakistan which covers $44 \%$ of its land and has predominantly loose soil with hyper arid climate. The province is located in the south western area of Pakistan in a desert belt, and having a location on the global map in between $250 \mathrm{~N}$ to $320 \mathrm{~N}$ and $600 \mathrm{E}$ to $720 \mathrm{E}$ of coordinates and covers an area of $347190 \mathrm{Km}^{2}(\mathrm{Naz}$ Mirza, et al., 2009).

Soil in Balochistan is facing numerous challenges such as desertification, land degradation, depletion of soil fertility, structural instability, high $\mathrm{pH}$ and low 
contents of organic matters. In the barren highlands of Balochistan, environmental effects are the most noticeable factors which result in the decrease of crop production. Fast growing population, regular droughts, frequent variations in climate, land degradation, desertification are the main challenges for environment and food security.

The conventional tillage (CT) system by continuous ploughing through tine cultivator and moldboard plough without retention of crop residues are delpeting soil organic carbon stock and promoting erosion losses. (Bowman, et al., 1990; Ussiri and Lal, 2009). In CT system of agricultural practices have depended on different forms of tillage to eliminate past crop residue, competing vegetation, incorporate soil amendments, and for planting purpose to prepare seedbed. Although, CT increase the crop yield but also have environmental and soil drawback observed. Such soils for a long period of time under CT can have adverse effects in relation to their physical, chemical and biological status, with the result that they may be incapable of maintaining their earlier level of production. As a result more and more fertilizers are resorted to along with machinery in order to sustain yields as the production system weakens and the quality of soil is lowered (Lampkin, 1998). It is mandatory to find out and manage options for betterment of soil organic carbon (SOC) in these areas (ICARDA, 2012).

The conservation tillage systems are being advocated worldwide for sustainable crop production. Zero tillage is known as method of soil farming in residues of preceding crop is left on fields earlier than and later than of growing the subsequent crop, to decrease soil erosion and runoff. To supply such conservation benefits, at least $30 \%$ of the soil surface have to be roofed with residue after planting the next crop (CTIC, 2004). (Lal, 1990) described conservation tillage as the way of seedbed preparation that involves residue mulch and an increase in surface roughness as the main factor. Soil quality has an enormous effect on level of production and environmental conditions, and the quality of soil is impacted by crop residue management and tillage methods (Karlen, et al., 1997; Wander and Drinkwater, 2000). According to (Doran et al., 1993) conservation tillage also help to improve soil structure, conserve soil moisture loss, improves soil water holding capacity, minimizes soil erosion problems and also to mitigate the emission of greenhouse gases through carbon sequestration and the cost of crop cultivation is decreased as compared to conventional soil tillage with a plough concentration of beneficial soil microorganisms will also increase which fixes essential plant nutrients. Soils having high level of SOC are means for the increased CEC, base saturation percentage (BSP), and available water capacity (De Moraes et al., 2009). Increased concentration of soil organic carbon is linked with increase in soil aggregate stability this aggregation is associated with less erosion and runoff (Dell et al., 2008; Devine et al., 2011). An important example of conservation tillage is zero tillage (ZT), which is well-known as direct drilling method, through which seeds are sown using a special seed drill into the unploughed soil. Other research works also demonstrated that eliminating conventional agricultural tillage practices provide an opportunity to sequester anthropogenic carbon dioxide into SOC (Jarecki and Lal, 2003; Paustian Six et al., 2000; West and Marland, 2002).

Little information is available under conservation tillage for their effect on sorghum (Sorghum bicolor) crop yield and soil properties in upland cropping systems of Balochistan. The benefits of using ZT depend both the type of soil as well as weather condition i.e. precipitation. The effect of ZT on soil type is the fact that ZT changes soil physical, chemical as well as biological properties. The limit and extreme effect of such changes as a result of the zero tillage method in soil is apparently consequent upon soil texture, in clayey soil such variation take place rapidly and go deeper in comparison with sandy soils. Some argue that sandy soils are not fit for zero tillage. In Quetta, Pakistan over $65 \%$ of productive land comprises of silty soils. Keeping in mind the above issues regarding the province, a research experiment was conducted in the field area of Balochistan Agriculture College, Quetta (BAC) under following objectives i) Compare conventional and conservation tillage practices for their effects on soil physical and chemical properties ii) Compare conventional and conservation tillage practices for their effects on summer sorghum crop production.

\section{Material and Methods}

\section{Location}

Conservation tillage experiment was initiated in 2016 on a silty loam soil at the field area of Balochistan 
Agriculture College, Quetta (atitude $30.1830^{\circ} \mathrm{N}$, longitude $\left.66.9987^{\circ} \mathrm{E}\right)$ in the upland of Balochistan, Pakistan. The soil has sand $130 \mathrm{~g} \mathrm{~kg}^{-1}$, silt $750 \mathrm{~g} \mathrm{~kg}^{-1}$ and clay $120 \mathrm{~g} \mathrm{~kg}^{-1}, \mathrm{pH}$ value above 8.0 and SOC 4.2 $\mathrm{g} \mathrm{kg}^{-1}$. The climate of the experimental site is hyperarid, very cold in winter and moderate in summer with $98 \%$ of the rain received during winter in the form of heavy snowfall or slow rain. The farmers of this area conventionally grow cereal crop i.e. wheat, sorghum and maize through intensive plowing and without retention of any organic amendments.

\section{Treatments}

The experiment was placed in a Randomized Complete Block Design having four replications of each $38 \times 11 \mathrm{~m}$ plots. The three tested tillage systems were Conventional Tillage (CT), Zero Tillage (ZT) and Chisel Plough $(C P)$. The experiment was initiated in an area of 5600 $\mathrm{m}^{2}$ with treatments arranged in the Randomised Complete Block (RCBD). The main plot treatments were tillage practices, i.e. conventional tillage $(\mathrm{CT})$ as $\mathrm{T}_{1}$, zero tillage (ZT) as $\mathrm{T}_{2}$ and in chisel plough (CP) as $\mathrm{T}_{3}$. In CT plots the soil was ploughed upto $20 \mathrm{~cm}$ depth with tine cultivator upto 7-8 time for weed control, moisture conservation, seed-bed preparation and sorghum crop was sown with seed-cum-fertilizer drill. In ZT, field remained undisturbed in the entire period and weeds were controlled with roundup herbicide when needed and sorghum crop was sown directly with a zero tillage seed drill. In $\mathrm{CP}$, one time chisel plough upto $25 \mathrm{~cm}$ depth was applied at the start and after that weeds were controlled with roundup herbicide (Glyphosate @ $1 \mathrm{~L}$ acre ${ }^{-1}$ ) and crop was sown through direct drilling with zero tillage drill. The recommended doses of fertilizer NPK i.e. 100-60-30 in the form of urea, diamonium phosphate (DAP) and sulfate of potash (SOP) were used. Sorghum crop was sown in all plots by seed rate of was according to $25 \mathrm{~kg} \mathrm{ha}^{-1}$.

\section{Soil analysis}

Soil samples were collected from each replicated plot upto $30 \mathrm{~cm}$ depth in soil. Samples were taken through different tools for different purposes. Samples for texture, soil $\mathrm{pH}$, electrical conductivity, Total Organic Carbon (TOC) collected through soil auger. For bulk density and aggregate stability, sampling was done through core sampler.

\section{Total organic carbon}

One gram of air-dried soil sample was taken in to a $500 \mathrm{ml}$ conical flask. $10 \mathrm{ml}$ of $1 \mathrm{~N}$ potassium dichromate $\left(\mathrm{K}_{2} \mathrm{Cr}_{2} \mathrm{O}_{7}\right)$ along with $20 \mathrm{ml}$ concentrated $\mathrm{H}_{2} \mathrm{SO}_{4}$ (sulfuric acid) were added. The suspension was mixed and allowed to stand for $30 \mathrm{~min}$. After cooling $200 \mathrm{ml}$ DI water and $10 \mathrm{ml}$ of orthophosphoric acid $\left(\mathrm{H}_{3} \mathrm{PO}_{4}\right)$ concentrated were added and then allowed to cool. After that 10-15 drops of diphenylamine were added as indicator and placed the flask on magnetic stirrer. After stirring, solution titrated against $0.5 \mathrm{M}$ ferrous ammonium sulfate and color changed from violet-blue to light-green was noted (Walkley, 1947).

\section{Infiltration rate}

Infiltration rate was measured by single ring method. After removing surface litter wetted the area and ring was vertically derived in to the soil, and a scale placed inside for water infiltration measurement. Time and water level was recorded up to coming steady state level.

\section{Soil water content}

Soil samples were taken before one day of harvesting and sowing of the crop. $50 \mathrm{~g}$ of fresh soil samples from each plot were weighed and then dried at 105 ${ }^{\circ} \mathrm{C}$ in the oven for 24 hours. Samples were taken out from the oven and dry weights were calculated after cooling soil moisture was calculated (Hesse, 1971).

\section{Soil reaction ( $p H$ )}

In a glass beaker, $50 \mathrm{~g}$ of air-dried soil sample was taken, and then $50 \mathrm{ml}$ of distilled water were added. The contents were mixed for some time and allowed to stand for one hour. After this, soil $\mathrm{pH}$ was measured by using the $\mathrm{pH}$ meter (Thomas, 1996).

\section{Electrical conductivity}

Soil sample of $300 \mathrm{~g}$ were taken in a plastic container. Water was added and extract of saturated paste was taken. Conductivity meter was calibrated with $0.01 \mathrm{~N}$ $\mathrm{KCl}$ solution and electrical conductivity of the extract was measured with the EC meter (Rhoades, 1996).

\section{Bulk density}

Bulk density was determined from core samples. Core sampler was pressed into soil so that inner metal cylinder was filled uniformly. The soil carefully removed from the inner cylinder. After weighting sample kept in oven at $105^{\circ} \mathrm{C}$. Bulk density was calculated by dividing weight of oven dry soil with volume of core sampler (Black, 1965). 
Total porosity

The total porosity was calculated from bulk density and particle density (Black, 1965).

\section{Soil temperature}

Soil temperature was measured by soil thermometer.

\section{Soil texture}

Forty gram of soil sample was taken and treated with $\mathrm{H}_{2} \mathrm{O}_{2}$ for removing organic carbon. Sixty $\mathrm{ml}$ of sodium hexametaphosphate was added, shaken and transferred into graduated cylinder to make the volume up to $1000 \mathrm{ml}$. Density was recorded by hydrometer at specific intervals and soil textural class were determined by textural triangle (Bouyoucos, 1927; Bouyoucos, 1962).

\section{Crop parameters}

Shoot biomass were recorded by harvesting the crop from each plot and then weighing after oven drying. Grains at maturity were separated from spikes and average grain yield was presented in $\mathrm{Mg} \mathrm{ha}^{-1}$.

\section{Statistical analysis}

The data collected for various characteristics was subjected to Analysis of variance (ANOVA) and means obtained were compared at 5\% level of significance by Least Significance Difference (Steel et al.,1997) (Figure 1).

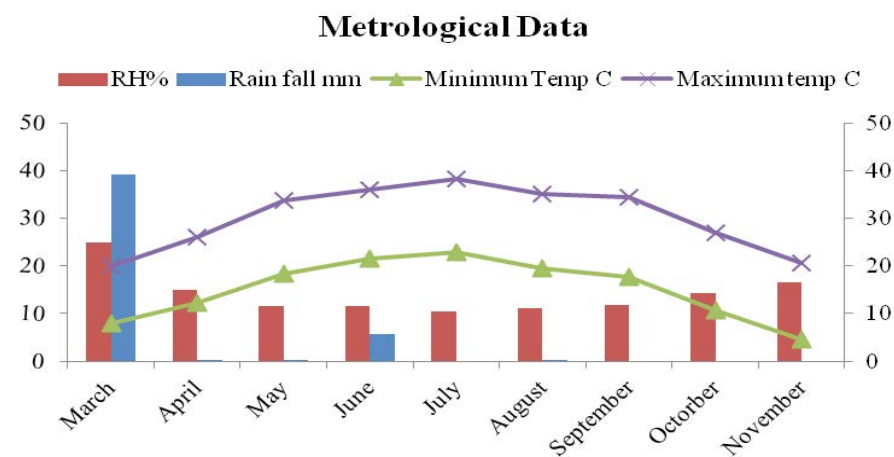

Figure 1: Metrological Data of Area representing Rainfall, Relative Humidity Minimum and Maximum temperature for growing period.

\section{Results and Discussion}

\section{Total Organic Carbon (TOC)}

The results pertaining to TOC \% were significant $(\mathrm{P} \leq 0.05)$ for $\mathrm{ZT}(0.48 \%)$ treatment after harvest (Figure 2). While the CT (0.28\%) and CP (0.35\%) did not show a significant difference of TOC \% but a noticeable numerical difference was found between these two treatments after harvest.

Usually soil depth effects the concentration of SOC accumulation for different tillage systems. The results are obtained from the surface analysis of $0-6 \mathrm{~cm}$ of soil depth, therefore ZT treatment showed a significant change (Martínez Fuentes et al., 2008). The same was responded by (Kiluk, 2014) that the depth had a mane significant effect on SOC.

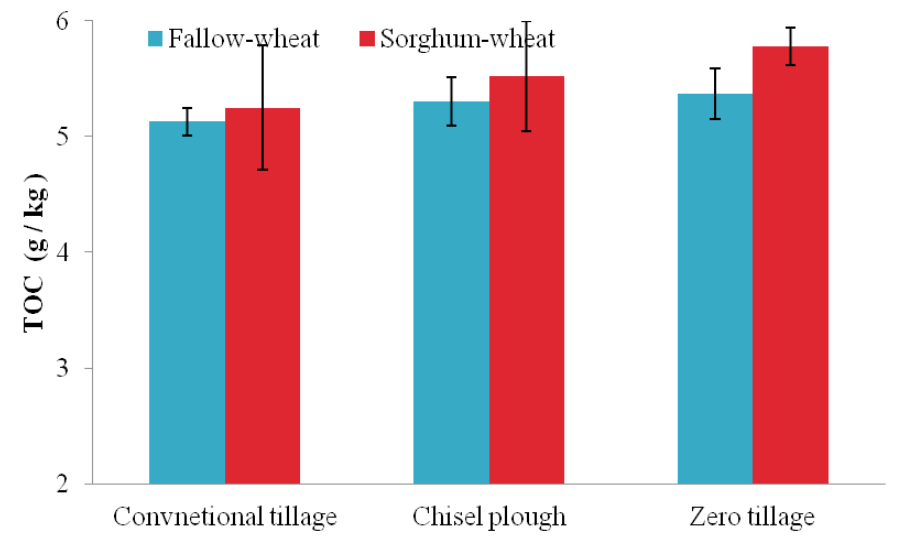

Figure 2: Changes in soil total organic carbon under conservation tillage in loess dryland soils.

\section{Infiltration rate}

The steady state infiltration rate were not significantly $(\mathrm{P} \leq 0.05)$ affected by tillage practices (Figure 3$)$. A minor improvement of infiltration rate was seen in ZT treatment after harvest $(0.66 \mathrm{~cm} / 5 \mathrm{~min})$. The negligible changes were observed for $\mathrm{CT}$ and $\mathrm{CP}$ in infiltration rates before and after harvest of summer sorghum crop. The greatest difference for before and after harvest was observed in ZT among both of the other treatments.

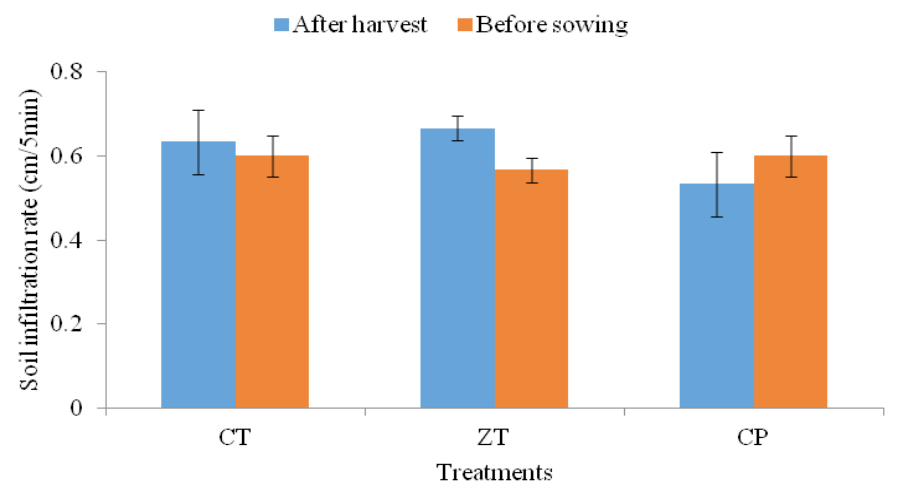

Figure 3: Steady state infiltration rate under different tillage treatments for before sowing and after harvest of summer sorghum crop in 2016, at BAC, Quetta.

A minor improvement of steady state infiltration rate of ZT treatment was probably due to un disturbance of soil through tillage and avoidance of heavy traffic, 
therefore plow pans of underneath's horizon could not be created, hence allowing the percolation of water in deep. In undisturbed soil the structure of soil was not broken down and also the habitats of soil living organisms were not destroyed, therefore population of microbes, earth worms and rodents might be increased making the soil porous and so caused more infiltration. In north-western Canada, (Arshad et al., 1999) also demonstrated that steadystate infiltration rate was $60 \%$ greater for no-tillage than for conventional tillage after 12 years.

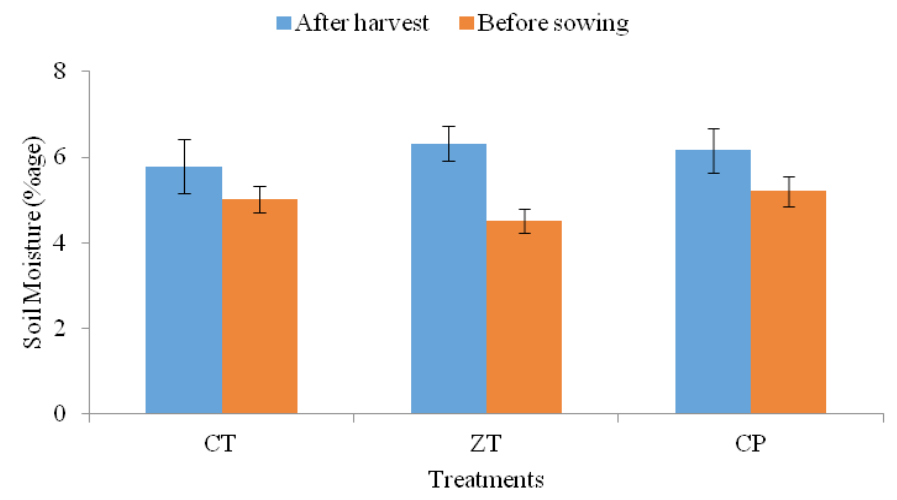

Figure 4: Soil moisture percentage under the different tillage treatments for before sowing and after harvesting the sorghum crop during 2016 at BAC, Quetta.

\section{Soil Water Content (SWC)}

The results of soil water content in percentage under different tillage practices shown in Figure 4. The water content was not significantly affected by different tillage practices after harvest $(\mathrm{P} \leq 0.05)$. ZT $(6.32 \%)$ tillage treatment has shown comparatively highest water content in percentage as compared to other two tillage treatments (CT (5.79\%), CP (6.16\%).

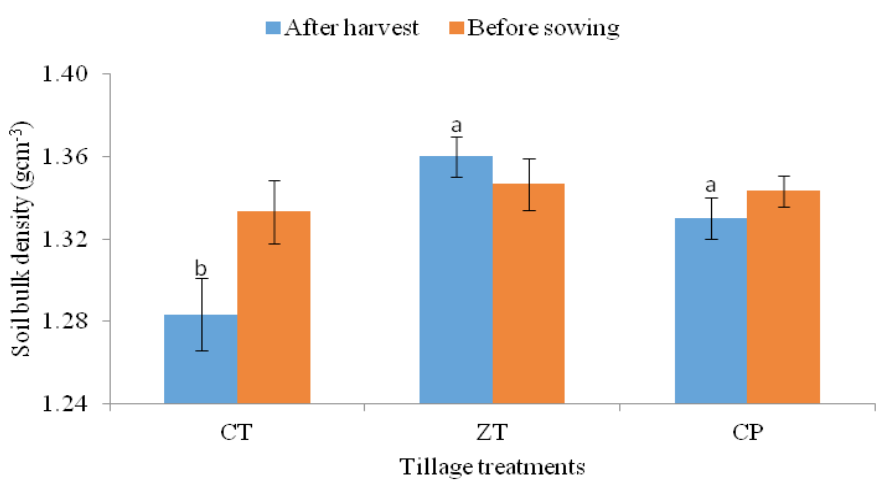

Figure 5: Soil bulk density under the different tillage treatments for before sowing and after harvesting the sorghum crop during 2016 at $B A C$, Quetta.

Before sowing water \%age was recorded low as compared to after harvest because of high temperature in the month of August caused evaporational losses of water from the top soil layer, while after harvest analysis were carried out in the month of November which resulted a higher moisture content due to low evaporation rate and low temperature. The results correlate with (Bescansa et al., 2006) who did not found significant results for soil water content in relation to different tillage practices.

\section{Soil reaction ( $p H)$}

The results regarding to $\mathrm{pH}$ of the soil extract gradually decreased in ZT from time of sowing (8.03) to harvesting (7.9) as shown in Figure 5. But there was no significant pair wise mean difference in results among three tillage treatments for soil $\mathrm{pH}(\mathrm{p} \leq 0.05)$. From the results obtained it was clear that there was almost no change in $\mathrm{pH}$ of before sowing (7.95), (8.0) and after harvesting (8.0), (8.0) for CT and CP respectively.

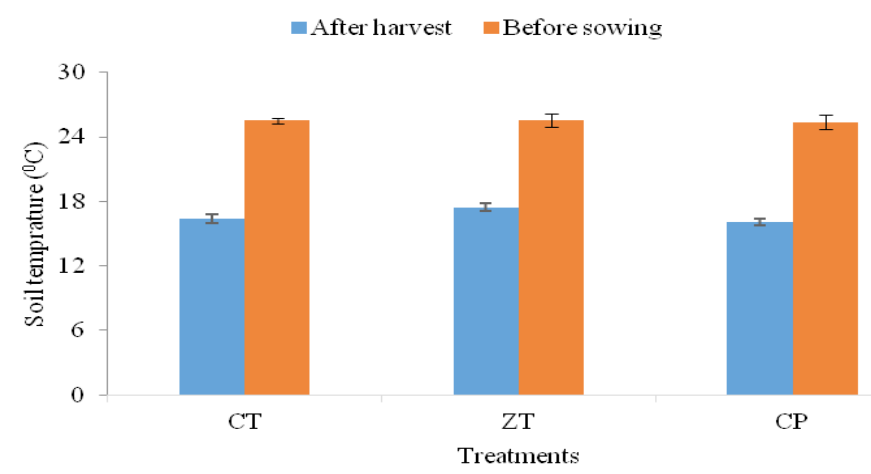

Figure 6: Soil temperature under the different tillage treatments for before sowing and after harvesting the sorghum crop during 2016 at $B A C$, Quetta.

A minor decrease of $\mathrm{pH}$ in $\mathrm{ZT}$ treatment was due to none disturbance of soil which enhanced the microbial activity and decomposition took place, which eventually released the carbonic acid in to the soil, so as a result the $\mathrm{pH}$ of soil decreased. The results were related to the findings of (Tarkalson Hergert et al., 2006) who reported 9 per cent decrease in soil $\mathrm{pH}$ under NT as compared to CT due to enhancement of acidification.

\section{Electrical Conductivity (EC)}

The data pertaining to EC as affected by tillage practices were not significantly different $(p \leq 0.05)$ as shown in Figure 6. EC of ZT treatment gradually decreased $\left(0.31 \mathrm{dSm}^{-1}\right)$ from the pre sowing EC condition (0.32 $\mathrm{dSm}^{-1}$ ) of the same treatment of RCBD experimental plot, While no change was observed in $\mathrm{EC}$ of $\mathrm{CT}$ and $\mathrm{CP}$ treatments before sowing $\left(0.325 \mathrm{dSm}^{-1}\right),(0.328$ $\left.\mathrm{dSm}^{-1}\right)$ and after harvesting $\left(0.32 \mathrm{dSm}^{-1}\right),(0.324$ 
$\mathrm{dSm}^{-1}$ ) respectively.

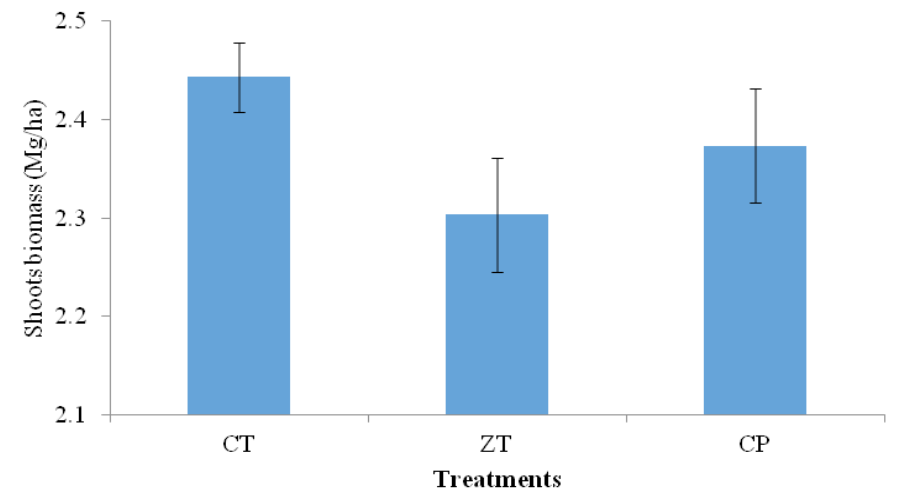

Figure 7: Summer sorghum crop shoot biomass under different tillage treatments in 2016, at BAC, Quetta.

From the results EC of ZT bit decreased hopefully due to the compactness of soil surface which decreased the evaporation rate due to which the salts in soil solution could not reached on the surface. The other reason was that the zero tillage $(\mathrm{ZT})$ system improved the infiltration rate due to which salts in soil solution leached down with percolating water hence the EC of soil is decreased. (Kahlon and Gurpreet, 2014) also observed the mean highest EC under Conventionally tilled soil (CT) and low EC under ZT in two different soil types (SL and LS).

\section{Soil bulk density}

The results pertaining to the bulk density of soil (0$15 \mathrm{~cm})$ expressed in Figure 5. The significant $(\mathrm{P} \leq 0.05)$ lowest bulk density was observed in $\mathrm{CT}$ treatment $\left(1.28 \mathrm{gcm}^{-3}\right)$ as compared to ZT $\left(1.36 \mathrm{gcm}^{-3}\right)$ and CP $\left(1.33 \mathrm{gcm}^{-3}\right)$ after harvest. There was approximately similar bulk density of each treatment before sowing.

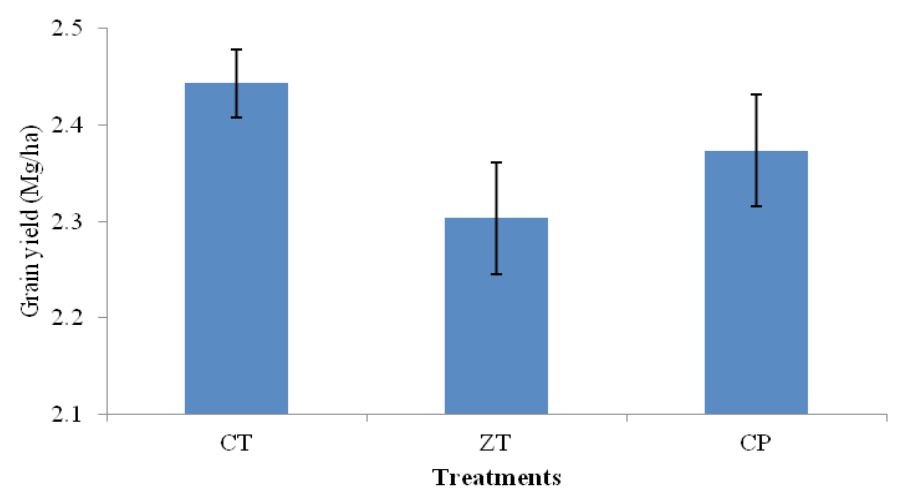

Figure 8: Grain yield of summer sorghum crop under different tillage systems in 2016, at BAC, Quetta.

A significant decrease in the bulk density of CT treatment was due to plowing, which mad soil very porous and wide spaces were created. Conversely ZT showed highest bulk density but not significant from
$\mathrm{CP}$, both of the conservation tillage treatments were not disturbed through plowing, hence soil became compacted at the surface resulting higher bulk density. The results were in correspondence to the work of $(\mathrm{He}$ et al., 2009) who observed the higher bulk density under ZT treatment plots and lower bulk density of CT treatment near to the surface.

\section{Soil porosity}

The statistical results for soil porosity of CT (52\%) was significantly $(\mathrm{P} \leq 0.05)$ higher than ZT $(50 \%)$ treatment, while $\mathrm{CP}$ (51\%) showed the mean pair wise relation to both of $\mathrm{CT}$ and $\mathrm{ZT}$ treatments as shown in Figure 6 for harvest. Before sowing, there was no significant difference observed under different tillage treatments for soil porosity.

The soil porosity is inversely proportional to the bulk density of soil. From the previous results of bulk density discussed, CT showed lowest bulk density, therefore the porosity of the same treatment increased due to loosening of compacted soil by inversion and pulverization, on the other hand $\mathrm{ZT}$ tillage treatment showed lowest porosity due to most compactness of soil and highest bulk density, and the CP in between both of these treatments. These results are in line with those found by (Lipiec et al., 2006).

\section{Soil temperature}

The results regarding to soil temperature showed in Figure 6. The means of three tillage treatments were not significantly different at critical value of $(p \leq 0.05)$. The soil temperature readings for ZT and CT were almost same $\left(16.76{ }^{\circ} \mathrm{C}\right.$ and $\left.16.73{ }^{\circ} \mathrm{C}\right)$ respectively, but $\mathrm{CP}$ showed little bit less soil temperature reading $\left(16.06{ }^{\circ} \mathrm{C}\right)$.

Initial soil temperature of treatments was almost same before sowing i.e. $25.370 \mathrm{C}, 25.50 \mathrm{C}$ and $25.50 \mathrm{C}$ for $\mathrm{CP}, \mathrm{CT}$ and $\mathrm{ZT}$ respectively. The before sowing temperature was high because of warm weather condition in the month of August, while after harvest readings were taken in the month of October there for the temperature of soil also dropped down. The results were not significant, but $\mathrm{ZT}$ showed a minor high temperature, the reason is that in $\mathrm{ZT}$ treatment sorghum crop was sown without disturbing the soil. So therefore microbial population increased, and greater amount of organic decomposition took place releasing the $\mathrm{CO} 2$ gases, eventually the temperature of soil increased as compared to other tillage treatments 
in which soil was totally plowed for the purpose of seed bed preparation. The results of soil temperature were in accordance with the work of (Gauer et al., 1982) when he observed higher soil temperature in ZT treatments than CT treatments in plots without straw was spread on soil surface.

\section{Sorghum dry shoot biomass}

The results of shoot biomass in $\mathrm{Mg} / \mathrm{ha}$ of summer sorghum crop shown in Figure 7. Results showed not significant $(\mathrm{P} \leq 0.05)$ difference in grain yield of three tillage treatments. $\mathrm{CT}$ showed numerically highest sorghum dry shoot biomass yield converted from $\mathrm{g} /$ $\mathrm{m} 2$ to $\mathrm{Mg} / \mathrm{ha}$ (2.44 Mg ha-1) followed by CP (2.37 $\mathrm{Mg}$ ha-1), while lowest yield observed in ZT (2.30 $\mathrm{Mg}$ ha-1) in semi arid climatic condition of Quetta, Balochistan Pakistan.

The biomass of $\mathrm{CT}$ was significantly higher than that of the ZT, because of the same reasons discussed in case of grain yield. The $\mathrm{CP}$ tillage treatment was in middle of $\mathrm{CT}$ and $\mathrm{ZT}$ for the purpose to pulverize the soil for seed bed preparation there for the shoot biomass yield also recorded in between the both of $\mathrm{ZT}$ and $\mathrm{CT}$ treatments.

\section{Sorghum grain yields}

The results of grain yield in $\mathrm{Mg} / \mathrm{ha}$ of summer sorghum crop shown in Figure 8. Results showed significant $(\mathrm{P} \leq 0.05)$ difference in grain yield of $\mathrm{CT}(1.60 \mathrm{Mg}$ ha1) and ZT (1.31 Mg ha-1) tillage treatments, while $\mathrm{CP}(1.40 \mathrm{Mg}$ ha-1) did not significantly differed with both of $\mathrm{CT}$ and ZT.

The differences among the yield of three tillage treatments were recorded at compromise able level. The conventional tillage treatment $(\mathrm{CT})$ normally yielded according to area conditions, while in $\mathrm{CP}$ and $\mathrm{ZT}$ a minute decrease in yield was observed due to compactness of soil, eventually affected the seed germination percentage, and root penetration deep in layer, hence the crop nourishment possibly be affected due to which conservational tillage treatments resulted bit lower yield. (Mishra et al., 2010) reported tillage practices did not influence on wheat grain yield.

\section{Conclusion and Recomendations}

It is concluded that conservation tillage in the form of zero tillage and chisel plow has potential to improve soil properties, especially buildup of soil organic carbon and reduce input cost while provide sufficient crop yield. It is recommended to continue this experiment upto longer period and replicate different location in Balochistan to confirm and avail the utmost benefit of conservation tillage

\section{Acknowledgements}

We are thankful to Centre for Advanced Studies in Agriculture and Food Security in University of Agriculture Faisalabad (CAS-AFS-UAF) and the Punjab Agriculture Research Board for providing research grant regarding the conduction of this experiment in the degraded land of Balochistan, Pakistan.

\section{Authors Contribution}

Muhammad Sharif: Main author of the research article, conducted research experiment, prepared full text and graph if the article

Sadullah: Conducted research experiment, analysed soil sample, prepared full text and graph of the article. Ghulam Rasool: Support writing of research article.

Muhammad Nasir Khan: Support analysis of samples.

Zubair Rehman and Ahmed Khan: Support conduction and management of field experiment.

Ijaz Ahmad: Reviewed the article and proposed fruitful suggestions.

Khalid Hussain: Reviewd the article and helped for analysis of result in statistical software.

\section{References}

Arshad, M., A. Franzluebbers and R. Azooz. 1999. Components of surface soil structure under conventional and no-tillage in northwestern Canada. Soil Tillage Res. 53: 41-47. https:// doi.org/10.1016/S0167-1987(99)00075-6

Baker, C.J.2007.No-tillage seedling in conservation agriculture. p. 626p.

Bescansa, P., M. Imaz, I. Virto, A. Enrique and W. Hoogmoed. 2006. Soil water retention as affected by tillage and residue management in semiarid Spain. Soil Tillage Res. 87: 19-27. https://doi.org/10.1016/j.still.2005.02.028

Black, C.A. 1965. Methods of soil analysis part 1 and 2 .

Bouyoucos, G.J. 1927. The hydrometer as a new method for the mechanical analysis 
of soils. Soil Sci. 23: 343-354. https://doi. org/10.1097/00010694-192705000-00002

Bouyoucos, G.J. 1962. Hydrometer method improved for making particle size analyses of soils. Agron. J. 54: 464-465. https://doi. org/10.2134/agronj1962.00021962005400050 028x

Bowman, R., J. Reeder and R. Lober. 1990. Changes in soil properties in a central plains rangeland soil after 3,20, and 60 years of cultivation1. Soil Sci. 150: 851-857. https://doi. org/10.1097/00010694-199012000-00004

Busari, M.A., S.S. Kukal, A. Kaur, R. Bhatt and A.A. Dulazi. 2015. Conservation tillage impacts on soil, crop and the environment. Int. Soil Water Conserv. Res. 3: 119-129. https://doi. org/10.1016/j.iswcr.2015.05.002

CTIC. 2004. National crop residue management survey. Conserv. Technol. Inf. Center: West Lafayette, IN.

Dell, C., P. Salon, C. Franks, E. Benham and Y. Plowden. 2008. No-till and cover crop impacts on soil carbon and associated properties on Pennsylvania dairy farms. J. Soil Water Conserv. 63: 136-142. https://doi.org/10.2489/ jswc.63.3.136

Devine, S., D. Markewitz, P. Hendrix and D. Coleman. 2011. Soil carbon change through $2 \mathrm{~m}$ during forest succession alongside a 30 -year agroecosystem experiment. For. Sci. 57: 36-50.

de Moraes Sa, J. C. Cerri, R. Lal, R. Dick, W. A. de Cassia., M. Piccolo, B. E. Feigl. 2009. Soil organic carbon and fertility interactions affected by a tillage chronosequence in a Brazilian Oxisol. Soil Tillage Res. 104(1): 56-64.

Doran, J., G. Varvel and J. Culley. 1993. Tillage and residue management effects on soil quality and sustainable land management. Int. Works. Sustainable Land Manage. Lethbridge: 15-24.

Gauer, E., C. Shaykewich and E. Stobbe. 1982. Soil temperature and soil water under zero tillage in Manitoba. Can. J. Soil Sci. 62: 311-325. https:// doi.org/10.4141/cjss82-035

He, J., Q. Wang, H. Li, J. Tullberg, A. McHugh, Y. Bai. 2009. Soil physical properties and infiltration after long-term no-tillage and ploughing on the Chinese Loess Plateau. N. Z. J. Crop Hortic. Sci. 37: 157-166. https://doi. org/10.1080/01140670909510261

Hesse, P.R. 1971. A textbook of soil chemical analysis. ICARDA. 2012. ICARDA Ann. Rep.
2012.

ICARDA. 2012. ICARDA Annual Report 2012.

Jarecki,M.K.and R.Lal.2003.Crop management for soil carbon sequestration. Crit. Rev.Plant Sci.22: 471-502. https://doi.org/10.1080/713608318

Kahlon, M.S. and S. Gurpreet. 2014. Effect of tillage practices on soil physico-chemical charactristics and wheat straw yield. Int. J. Agric. Sci. 4 (10): 289-293.

Karlen, D., M. Mausbach, J. Doran, R. Cline, R. Harris and G. Schuman. 1997. Soil quality: a concept, definition, and framework for evaluation (a guest editorial). Soil Sci. Soc. Am. J. 61: 4-10. https://doi.org/10.2136/ sssaj1997.03615995006100010001x

Kiluk, K.M. 2014. Impact of conservation tillage on soil organic carbon storage in Washtenaw County, MI.

Lal, R. 1990. Ridge-tillage. Soil Tillage Res. 18: 107-111. https://doi.org/10.1016/01671987(90)90053-G

Lampkin, 1998. Organic Farming. Farming Press, EEUU. Pp. 724.

Lipiec, J., J. Kuś, A. Słowińska-Jurkiewicz and A. Nosalewicz. 2006. Soil porosity and water infiltration as influenced by tillage methods. Soil Tillage Res. 89: 210-220. https://doi. org/10.1016/j.still.2005.07.012

Martínez, E., J.P. Fuentes, P. Silva, S. Valle and E. Acevedo. 2008. Soil physical properties and wheat root growth as affected by no-tillage and conventional tillage systems in a Mediterranean environment of Chile. Soil Tillage Res. 99: 232-244s. https://doi.org/10.1016/j. still.2008.02.001

Mishra, J., V. Singh and N. Jain. 2010. Long-term effect of tillage and weed control on weed dynamics, soil properties and yield of wheat in rice-wheat system. India. J. Weed Sci. 42: 9-13.

Naz-Mirza, S., M. Athar and M. Qayyum. 2009. Effect of drought on rangeland productivity and animal performance in dryland region of Balochistan, Pakistan. Agric. Conspectus Scientificus (ACS) 74: 105-109.

Paustian, K., J. Six, E. Elliott and H. Hunt. 2000. Management options for reducing $\mathrm{CO} 2$ emissions from agricultural soils. Biogeochem. 48: 147-163. https://doi. org/10.1023/A:1006271331703

Rhoades, J. 1996. Salinity: Electrical conductivity and total dissolved solids. Methods Soil Anal. 
Part 3 Chem. Method. 417-435.

Steel, R.G.D., J.H. Torrie and M.A. Boston. 1997. Priciples and procedure of statistics: A biometrical approach. Mc Graw Hill Inc. New York. pp. 633.

Tarkalson, D.D., G.W. Hergert and K.G. Cassman. 2006. Long-term effects of tillage on soil chemical properties and grain yields of a dryland winter wheat-sorghum/corn-fallow rotation in the Great Plains. Agron. J. 98: 26-33. https:// doi.org/10.2134/agronj2004.0240

Thomas, G. 1996. Soil pH and soil acidity. Methods of Soil Analysis Part 3, Chem. Methods: 475490.

Ussiri, D.A. and R. Lal. 2009. Long-term tillage effects on soil carbon storage and carbon dioxide emissions in continuous corn cropping system from an alfisol in Ohio. Soil Tillage Res. 104: 39-47. https://doi.org/10.1016/j. still.2008.11.008

Walkley, A. 1947. A critical examination of a rapid method for determining organic carbon in soils-Effect of variations in digestion conditions and of inorganic soil constituents. Soil Sci. 63: 251-264. https://doi. org/10.1097/00010694-194704000-00001

Wander, M.M. and L.E. Drinkwater. 2000. Fostering soil stewardship through soil quality assessment. Appl. Soil Ecol. 15: 61-73. https:// doi.org/10.1016/S0929-1393(00)00072-X

Wang, X., D. Cai, W. Hoogmoed, O. Oenema and U. Perdok. 2007. Developments in conservation tillage in rainfed regions of North China. Soil and Tillage Res. 93: 239-250. https://doi. org/10.1016/j.still.2006.05.005

West, T.O. and G. Marland. 2002. A synthesis of carbon sequestration, carbon emissions, and net carbon flux in agriculture: comparing tillage practices in the United States. Agric. Ecosyst. Environ. 91: 217-232. https://doi.org/10.1016/ S0167-8809(01)00233-X 